\title{
Utilization of Some Sugar Industrial by- Products and Fructan Storing Crops for Bioproduction of Citric Acid
}

\author{
Mona, I. Massoud ${ }^{1}$ and Mona H. Bekhet ${ }^{2}$
}

\begin{abstract}
Two sugar industrial by-products, cane bagasse "SCB" and sugar beet molasses "SBM" along with two fructan storing crops ,chicory roots" CR" and Jerusalem artichoke tubers "JA", alone or after mixing were utilized as a carbon source in fermentation medium to produce citric acid by Aspergillus niger strain GQ890276. It was found that the proximate composition and total sugars content of these agro-materials played a role in terms of citric acid production. Moisture ranged from 6.55 to $23.15 \%$; crude fat from zero to $1.55 \%$; crude protein from 3.27 to $8.53 \%$; crude fiber from zero to $47.46 \%$, ash from3.29 to $8.93 \%$,nitrogen free extract from 44.83 to $87.06 \%$ and total sugar 8.11 to $87.06 \%$ among these materials. The fermentation media either containing mixture of $\mathrm{CR}+\mathrm{SCB}$ and/or $\mathrm{CR}$ as carbon source gave high citric acid yield after 7 days of fermentation comparing with other used carbon sources. The citric acid yield was $59.36 \mathrm{~g} / \mathrm{L}$ in $\mathrm{CR}+\mathrm{SCB}$ medium .It was $87.80 \%$ when calculation was based on the amount of consumed fermentable sugars. Also this media gave the high biomass ( $22.90 \mathrm{~g} / \mathrm{L})$ yield.
\end{abstract}

\section{INTRODUCTION}

Citric acid has a variety of uses in food, pharmaceuticals and industrial fields (Rohr, 1998). It 's global production was more than one million ton per year (Papagianni, 2007). The fermentation production of citric acid is one of the large biotechnological industries. This process depends on using the filamentous fungus Aspergillus niger (Haq etal.,2004 Demirel et al.,2005). The economical production of citric acid by fermentation requires suitable inexpensive raw materials (Khosravi-Darani, and Zoghi,2008). In the two last decades, a considerable interest has been focused on using agricultural products and their wastes for citric acid production by Aspergillus niger (Khosravi-Darani et al., 2008). Bagasse and molasses are considered the main by-products of sugar industry. Bagasse represents nearly $30 \%$ of the sugar cane industry, meanwhile the produced molasses from using sugar beet in sugar production contains approximately $50 \%(w / w)$ total sugars $($ Leo, 1983). In other side, the discarded roots of chicory (Cichorium intybus) and Jerusalem artichoke tubers (Helianthus tuberosus, L.)

${ }^{1}$ Sugar Crops Research Institute, Agric. Research Center,

El-Sabahia, Alex. Egypt

${ }^{2}$ Food Science and Technology Dept, Faculty of Agric.,Univ of Alex,

El-Shatby., Egypt

Received October 14, 2010, Accepted December 5, 2010. due to their collection at late maturation stage are rich in inulin ,a polymer of fructose with $\beta$ 2-1 glycosidic linkage. (Gupta and Kaur,1997).

Therefore, in the present study the above mentioned raw agro-materials, sugar cane bagasse and sugar beet molasses, chicory roots and Jerusalem artichoke tubers, alone or after mixing were evaluated as a carbon source in fermentation medium used for citric acid bioproduction using Aspergillus niger strain GQ890276 which was previously isolated from Egyptian dry sugarcane bagasse, identified as A .niger isolate MonEg by amplification and sequencing of its $18 \mathrm{~S}$ rRNA (htttp://Www.ncbil. nlm.nih. gov/BLAST).

\section{MATERIALS AND METHODS}

\section{MATERIALS}

Sugar cane bagasse (SCB) was obtained from Technological Lab. at Sabahia Agric. Research Station, Alexandria ,Egypt . It was first cut into small parts then dried in an air oven (E. Schulg \& Co. Inh. Franz. KG) at $55^{\circ} \mathrm{C}$ for $12 \mathrm{hs}$ and ground in a mill (Retsch GM200Germany), sifted and kept in glass jars at room temperature $\left(25 \pm 2^{\circ} \mathrm{C}\right)$.

Sugar beet molasses (SBM) was obtained from Delta Beet Sugar Company, Kafr El-Sheikh Governorate, Egypt.

The roots of chicory (CR) (Cichorium intybus) at late maturity stage were obtained from the experimental farm of Faculty of Agriculture, Alexandria University ,Alexandria , Egypt. The tubers of Jerusalem artichoke "J.A'"(Helianthus tuberosus, L.) were obtained from Sabahia Horticultural Research Station Alexandria Egypt. The C.R and J.A samples were washed, sliced and rapidly immersed in $1 \%$ citric acid solution to avoid browning, then dried by hot air in a dryer at $55^{\circ} \mathrm{C}$, to constant weight, grounded to pass through 60 mesh sieve and kept in dry glass containers until further uses.

Aspergillus niger strain GQ890276 was obtained from Technological lab. at Sabahia Agric. Res. Station, Alex. Egypt. It was previously isolated from Egyptian dry sugarcane bagasse. Its $18 \mathrm{~S}$ rRNA was separated and purified according to instructions of Qiagen's DNeasy Kit (Qiagen, USA), amplified and its sequence were 
performed, according to the methods described by Guillemant and Drouard (1992). According to the obtained results of polymerase reaction (PCR) test and using Genbank database (http://www.ncbi.' nlm.nih. gov/BLAST), this strain of this mold was submitted into genbank database under accession No.GQ890276. Figure (1) showed the phylogenetic tree of $18 \mathrm{~S}$ rRNA of this isolated strain with $18 \mathrm{~S}$ rRNA of the other strains of this mold from the data obtained from genbank database.

\section{METHODS}

Fermentation process: The fermentation medium for citric acid production consisted of the following compounds ((per liter of distilled water)) as described by Kirimura et al (1986): $1.6 \mathrm{~g}$; Yeast extract, $3 \mathrm{~g}$; $\left(\mathrm{NH}_{4}\right) \mathrm{HPO}_{4}, 0.5 \mathrm{~g} ; \mathrm{KCL}, 0.5 \mathrm{~g} ; \mathrm{MgSO}_{4} .7 \mathrm{H}_{2} \mathrm{O}, 14 \mathrm{mg}$; $\mathrm{MnSO}_{4} \cdot 7 \mathrm{H}_{2} \mathrm{O}, 10 \mathrm{mg} ; \mathrm{FeCL}_{3} \cdot 6 \mathrm{H}_{2} \mathrm{O}$, and $120 \mathrm{~g}$ carbon source, from each of the following individual materials: sucrose, glucose, sugar beet molasses "SBM", sugarcane bagasse "SCB", chicory roots "CR", Jerusalem artichoke "JA", mixture of sucrose + SCB, molasses $+\mathrm{SCB}$ and $\mathrm{CR}+\mathrm{SCB}$ at $1: 1 \mathrm{w} / \mathrm{w}$ ratio. The $\mathrm{pH}$ of the medium was adjusted to 5.0 before distributing in flasks. The medium in the flasks were sterilized at $121^{\circ} \mathrm{C}$ for $15 \mathrm{~min}$. then cooled to ambient temperature. The mold strain was inoculated on potato dextrose agar (PDA) slants and incubated at $30^{\circ} \mathrm{C}$ for 4-6 days. The spores of the mold were suspended in 8 $\mathrm{ml}$ of sterile-distilled water (Difco,1974) to use as inoculums.The sterilized flasks containing fermentation medium were inoculated with $10 \mathrm{ml}$ of spore suspension containing about $1.7 \times 10^{8}$ spores $/ \mathrm{ml}$ after adding $4 \%$ (v/w) methanol as a promoting substance for citric acid production (Khosravi-Darani, and Zoghi ,2008). The flasks were incubated at $30^{\circ} \mathrm{C}$ in a rotatory incubator shaker (Innova 4230,Edison, NJ., USA) for 7 days at 200 rpm (Roukas, and Liakopoulou-Kyriakides ,2002)

Extraction of citric acid: At the end of the incubation period, the mycelia and other suspended solids were removed from the fermentation media by filtration, washed with $500 \mathrm{ml}$ of distilled water, drying at 105 then weighted. After filtration, the filtrates were centrifuged at $3500 \mathrm{~g}$ for $20 \mathrm{~min}$ at $-4^{\circ} \mathrm{C}$. Both citric acid and residual sugars were determined in the supernatant. Citric acid recovered from the supernatant by first precipitation as calcium citrate with calcium hydroxide then by acidificateion with sulphuric acid as following: the supernatant was frist heated to about $60^{\circ} \mathrm{C}$ then calcium hydroxide was added until the neutralization point. The precipitated calcium citrate was removed by filtration and washed several times with distiller water to remove residual sugar, treated with $0.2 \%$ sulfuric acid and filtered to obtain the mother liquor containing citric acid (Ruijter and Visser ,1999).

Analytical Methods: Moisture content, total solids, crude fiber, ash, protein, total sugars, inulin and crude ether extract were determined according to AOAC (1998). Nitrogen free extract (NFE) was calculated by difference. Reducing sugars were analyzed by the 3,5dinitrosalicyclic acid (DNS) method (Miller, 1959). Citric acid was determined by the colorimetric method of Marier and Boulet (1958).All experiments were conducted in triplicate.

Percentage of both yield of citric acid and utilized sugars during fermentation and volumetric productivity of citric were calculated using the following equations, (Lotfy et $a, 2007)$ :-

Yield of citric acid $(\%)=($ grams of citric acid produced $/$ grams of original sugar $) \times 100$

Sugar utilization $(\%)=($ grams of original sugar- grams of residual sugar / grams of original sugar ) $\times 100$

Volumetric productivity of citric acid $=\mathrm{g}$ citric acid produced per liter per hour.

Statistical analysis: The obtain values of the produced citric acid from using the different carbon sources were subjected to statistical analysis using CoStat Software (2004) computer program for statistics. Student-Newman-Keuls test was used to compare means at (0.05) significance level.

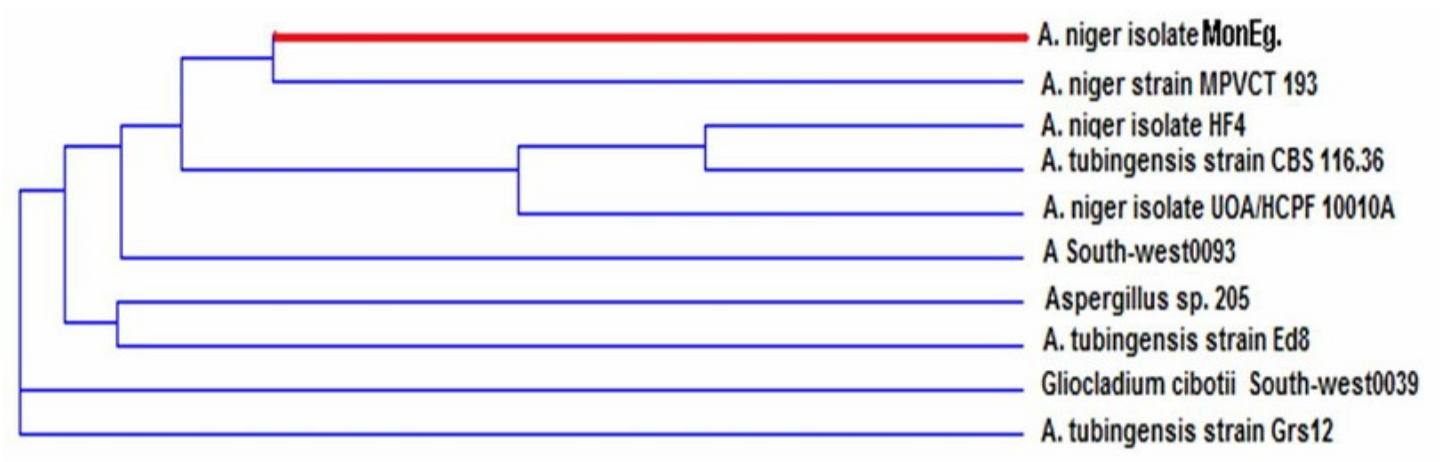

Figure1.Phylogenetic tree of 18S rRNA gene of MonEg. A.nige 


\section{RESULTS AND DISCUSSION}

1-Proximate composition and sugars of the utilized agro-materials:

Data presented in Table (1) indicated a significant diversity in proximate composition and sugars of the utilized agro-materials. Moisture content varied from 6.55 to $23.15 \%$ among such raw materials. It was high in sugar beet molasses (SBM), low in sugar cane bagasse (SCB) and medium in both chicory roots (CR) and Jerusalem artichoke (JA) tubers. Crude protein content was high in JA $(8.53 \%)$, low in SCB (3.27\% )and nearly closed in SBM (4.01\%) and CR (4.88\%). Crude fat did not detect in SBM and was very low in SCB , CR and JA. The SBM had the highest ash content $(8.93 \%)$, followed by JA $(7.69 \%), \mathrm{CR}(5.75 \%)$ and SCB $(3.55 \%)$ respectively.SCB had the highest fiber content (47.46\%) then CR(11.02\%), and JA (4.46\%). Meanwhile, SBM was free from this component. Nitrogen free extract was $87.06 \%$ in SBM, $78.06 \%$ in JA, $76.80 \%$ in CR and $44.83 \%$ in SCB. According to Beshay (2001) the bagasse of sugar cane contained 0.65 to $1.15 \%$ fat and 34.49 to $52 \%$ crude fiber. Monti et al., (2005) found that crude protein and ash ranged from 8.56 to $15.73 \%$ and 9.58 to $13.75 \%$, respectively in chicory roots. Also Praznik et al. (2002) and Amin, et al(2005) reported that the lipid, ash and protein contents were $0.9 \pm 0.5 \%, 4.3$ to $8.6 \%$, and $6.6 \%$ respectively in dried tubers of Jerusalem artichoke. The percentage of total carbohydrate of sugar cane bagasse, and chicory pulp was $45.30 \%$ and $65.53 \% \%$, respectively (Massoud ,2004).

As seen from data in table (1) total sugars was 8.11, $63.63,12.45$ and $21.38 \%$ in SCB, SBM, CR and JA,

respectively. Reducing sugars was lower (1.96\%) in CR, SCB and JA comparing with SBM. The latter raw material contained at least 4 to 5 times of reducing sugars content found in the other materials. These values are nearly similar with those mentioned by Leo, (1983), El-Sharkawy, (1998), Femenia et al.,(1998)and Massoud et al (2009) for the same materials .

Inulin was only detected in both CR $(33.67 \%)$ and JA(16.55\%), (Table 1). Such findings agree with the results of Patkai and Barta (2002). They reported that the inulin was $14-16.35 \%$ in JA.

\section{2-Bioproduction of citric acid:}

2.1-Effect of carbon sources: Results in Table(2) showed that the composition of the carbon sources in the fermentation medium influenced the yield of citric acid. Using disaccharides, sucrose, as carbon source gave higher yield of citric acid compared with monosaccharides, glucose. According to Kubicek and $\mathrm{R}$ ?hr (1989) the extracellular mycelium of A. niger bound invertase which at low $\mathrm{pH}$ becomes active and rapidly hydrolyzes sucrose to glucose and fructose, 2monosaccharides. Using sugar industrial byproducts, sugar beet molasses and cane bagasse as carbon source in fermentation medium gave lower yield of citric acid comparing with using sucrose, (Table 2 and Fig.2). This was due to the low available sugars $(8.11 \pm 0.52 \%)$ in bagasse and high level of both ash $(8.93 \pm 1.62 \%)$ and total sugars $(63.63 \pm 0.73 \%)$ in molasses .The studies of Islam et al, (1986); Kahlon, et $a l,(1991)$ and Grewal and Kalra, (1995) indicated that the presence of metal ions in molasses reduced from the bioproduction of citric acid by A.niger.

\section{Table. 1 Proximate composition, sugars and inulin of some agro- material (on dry weight}

\section{basis)}

\begin{tabular}{ccccc}
\hline Constituents \% & $\begin{array}{c}\text { Sugar cane } \\
\text { bagasse } \\
\text { (SCB) }\end{array}$ & $\begin{array}{c}\text { Sugar beet } \\
\text { molasses } \\
(\mathbf{S B M})\end{array}$ & $\begin{array}{c}\text { Chicory roots } \\
(\mathbf{C R})\end{array}$ & $\begin{array}{c}\text { Jerusalen artichoke } \\
\text { tubers } \\
(\mathbf{J} \text { A) }\end{array}$ \\
\hline Moisture & $6.55 \pm 0.99$ & $23.15 \pm 1.57$ & $7.16 \pm 1.09$ & $9.14 \pm 1.16$ \\
\hline Crude protein $(\mathbf{N} \times \mathbf{6 . 2 5})$ & $3.27 \pm 0.58$ & $4.01 \pm 0.22$ & $4.88 \pm 0.33$ & $8.53 \pm 0.15$ \\
\hline Crude fat & $0.89 \pm 0.27$ & 0.0 & $1.55 \pm 0.25$ & $1.26 \pm 0.08$ \\
\hline Ash & $3.55 \pm 1.05$ & $8.93 \pm 1.62$ & $5.75 \pm 0.81$ & $7.69 \pm 0.55$ \\
\hline Crude fiber & $47.46 \pm 1.78$ & 0.0 & $11.02 \pm 0.92$ & $4.46 \pm 0.16$ \\
\hline NFE* & $44.83 \pm 3.68$ & $87.06 \pm 1.84$ & $76.8 \pm 2.31$ & $78.06 \pm 0.94$ \\
\hline Total sugar & $8.11 \pm 0.52$ & $63.63 \pm 0.73$ & $12.45 \pm 0.80$ & $21.38 \pm 0.61$ \\
\hline Reducing sugar & $2.05 \pm 0.17$ & $11.5 \pm 1.30$ & $1.96 \pm 0.05$ & $2.77 \pm 0.08$ \\
\hline Inulin & $\mathrm{ND}^{* *}$ & $\mathrm{ND}^{* *}$ & $33.67 \pm 0.72$ & $16.55 \pm 1.05$ \\
\hline
\end{tabular}

*NFE: Nitrogen free extract

$* * \mathrm{~N}$ D:Not detected

Results are mean \pm SD of three determinations 


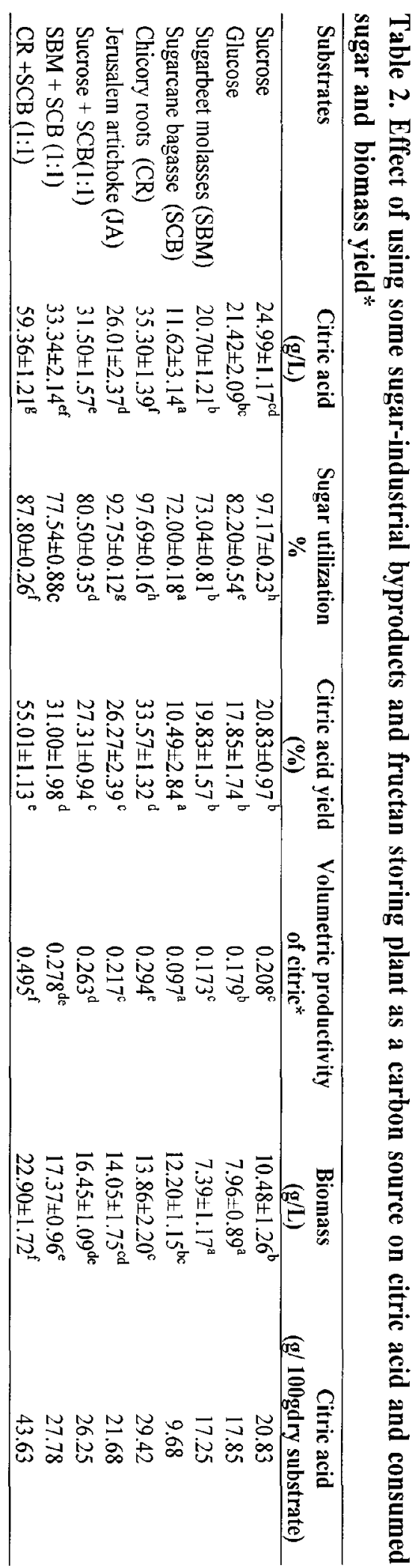


Honecker et al., (1989) found that the maximum yield of citric acid obtain when sugar content ranged from $14-22 \%$ in fermentation medium. Hossain et al. (1984) stated that adding carbon sources rich in total sugars in fermentation medium lead to suppress the activity of the enzymes produced by A.niger for the production of citric acid.

In the other side and as seen in Fig.(2) and Table (2) using each of fructan storing crops , chicory roots" CR" and Jerusalem artichoke tubers "JA", as a carbon sources in fermentation medium increased from the yield of citric acid than sucrose .Such increase may be attributed to the high level of inulin in both crops and especially in CR one. The latter crop had nearly the double amount of inulin in JA one, Table(1). Results of Massoud et al ( 2010) showed that A .niger strain GQ890276 produced inulinase enzyme. Therefore it is able to hydrolysis inulin of CR and JA into fructose in fermentation medium and sequentially increase from yield of citric acid. Also CR and JA tubers may contain some activators such as minerals and vitamins which play role as a coenzymes during bioproduction of citric acid and increase from it's yield.

The above results were confirmed from the calculation of the consumed sugars, Table(2).The highest amount of consumed sugars was from the media containing CR followed by sucrose ,JA, glucose ,SBM and SCB, respectively .

Using 1:1 w/w mixtures of sucrose+SCB, $\mathrm{SBM}+\mathrm{SCB}$ and $\mathrm{CR}+\mathrm{SCB}$ as a carbon sources in citric acid fermentation medium caused a significance increase in the acid yield. According to Kumar, et al (2003), sugarcane bagasse considered a suitable carrier in solid state fermentation method to produce citric acid by $A$. niger. Therefore it helps in increasing the yield of citric acid when used in previous mixtures.

The yield of citric acid in the fermentation medium containing $\mathrm{CR}+\mathrm{SCB}$ mixture was more by nearly $40 \%$ than that containing the other two mixtures, Table (2) and Fig.(2).

Generally ,there was a parallel relationship between yield of citric acid as $\mathrm{g} / \mathrm{L}$ and both percent of citric acid yield and as gram citric per 100 gram dry carbon source ,Table (2).

The highest production of biomass on dry weight was achieved when $\mathrm{CR}+\mathrm{SCB}$ mixture was used as a carbon source followed by both SBM+SCB and sucrose $+\mathrm{SCB}$, each of JA, CR, SCB then sucrose, both glucose, and SBM, respectively. This was due to differences in the growth rate of $A$.niger strain GQ890276 in the medium containing such different carbon sources.

2.2 Effect of fermentation time :This effect was studied in two fermentation mediums. The first contained SBM+SCB mixture and the second had $\mathrm{CR}+\mathrm{SCB}$ mixture as a carbon sources.

As illustrated in Fig (3),a gradual increase in both citric acid and biomass yields was obtained with extending fermentation time to 7 days. A contrast trend was noticed for residual sugars. The rate of such changes

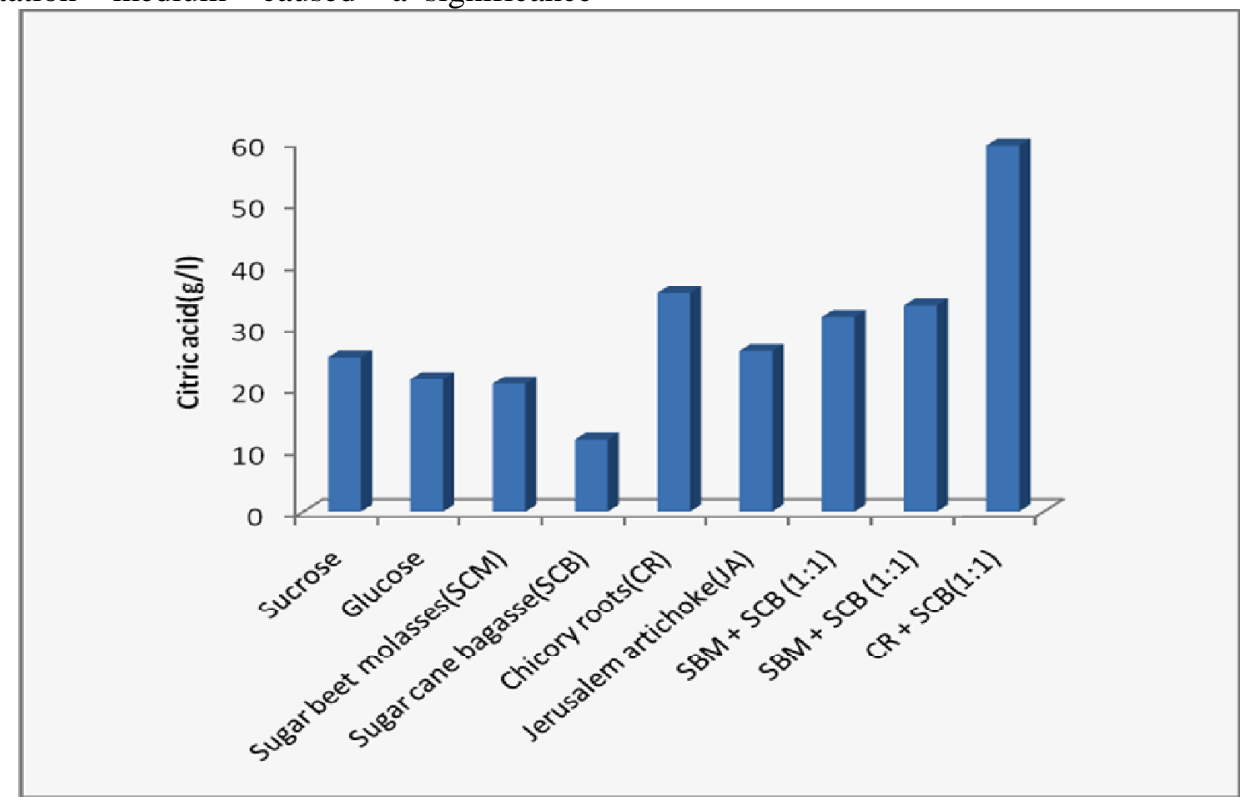




\section{Figure 2. Effect of using different agro-materials as carbon sources on the bioproduction of citric acid yield}
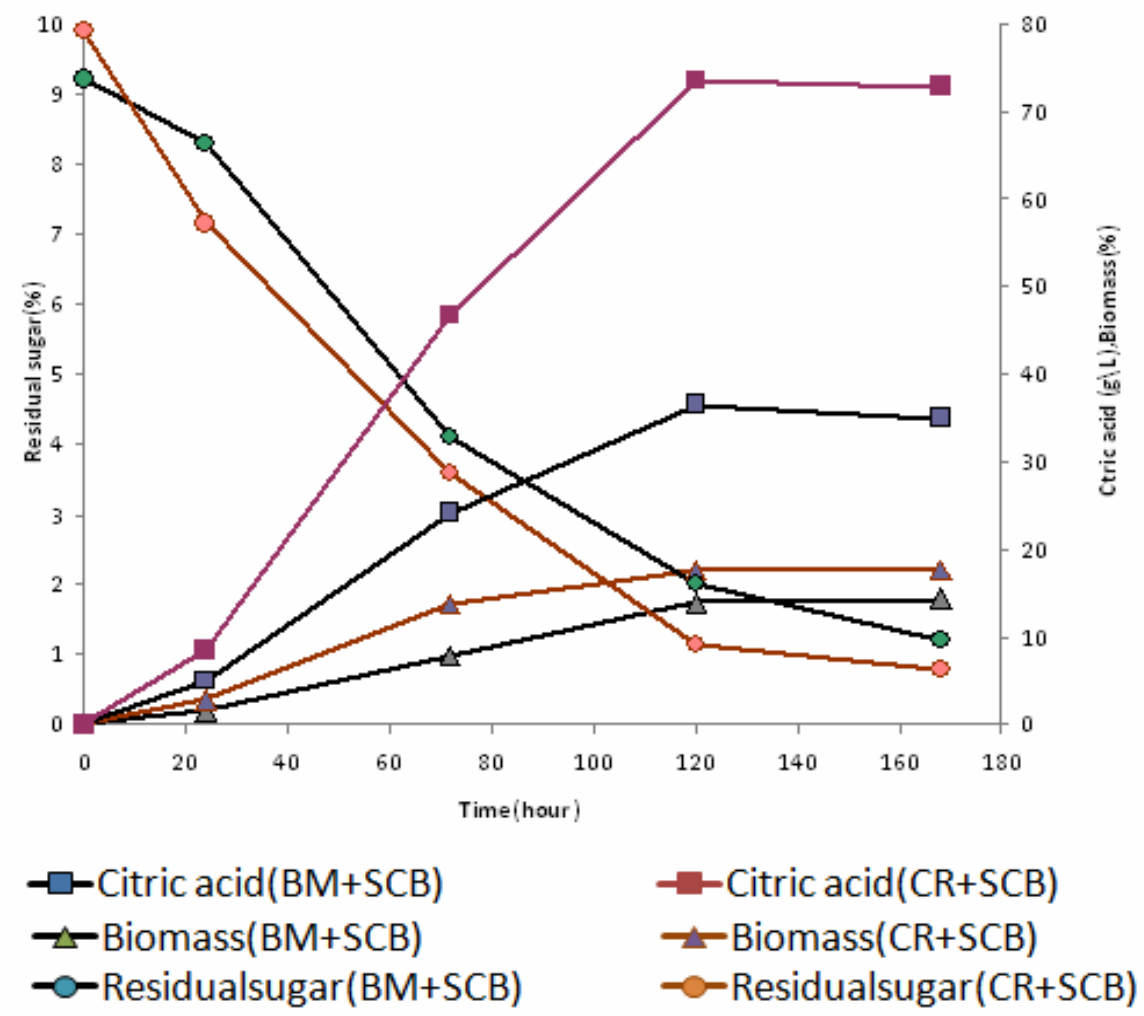

\section{Figure 3. Effect of fermentation period on the yield of citric acid, biomass yield and residual sugar content}

was differed according to both fermentation time and carbon source in medium. Generally a rapid acceleration rate for such changes was noticed through the first 5 days then turned to nearly stationary rate in the last 2 days of fermentation.As mentioned before, the yield of citric acid and biomass was higher and the residual sugar content was lower in fermentation medium containing $\mathrm{CR}+\mathrm{SCB}$ than having SBM + SCB as a carbon source. Khosravi-Darani et al (2008) used pretreated and untreated straw as a carbon source to produce citric acid and found that the optimum fermentation time was 7 days. Kumar et al (2003) used fruit wastes for citric acid production using solid state fermentation process and found that maximum yield of citric acid was achieved after 9 days of fermentation.

\section{REFERENCES}

Amin, A. Wafaa, Massoud,I. Mona and Attia,R.S. (2005). Some specified products prepared from Jerusalem Artichoke (helianthus tuberosus, 1.) Tubers Alex. J. of Agric. Res. 50, 75-81
A.O.A.C. (1998). Official Methods of Analysis. 16 ${ }^{\text {th }}$ (ed.) Association of Official Analytical Chemist. Gaitherburg, Maryland, 20877-2417 U.S.A.

Beshay, Maria, G. (2001). Chemical composition and nutritive values of various cane by products as affect by variety and drying method. Egypt. J. Applied Sciences. 16, 83-98.

Co-Stat.Software(2004). User's Manual Version. Cohort Tusson, _ _ . . . Arizona _ _ ISA. htti/hwww. Cohort.com.info@ @ohort.com

Demirel, G., Yaykas, K. O. and Ahmet Y(2005). The production of citric acid by using immobilized Aspergillus niger A-9 and investigation of its various effects .Food Chemistry. 89, 393-396.

Difco (1974).Manmal of Dehyrated Culture Media and Reagents of Microbiological and Clinical Laboratory Procedures, Ninth Edition. Reprinted. Difco Laboratores. Detriol, Michigan,USA.

El-Sharkawy,Z.A.A.(1998). Physiological Studies on Jerusalem Artichoke. Ph.D.Thesis. Vegetable Crops Department, Faculty of Agriculture, Cairo Univ., Cairo, Egypt. 
Femenia, A., Robertson, J.A., Waldron, K.W., and Selvendran, R.R. (1998). Cauliflower, globe artichoke and chicory, processing by- products as sources of dietary fiber. J.Sci. Food Agric.77, 511-518.

Grewal, H.S. and Kalra, K.L. (1995). Fungal production of citric acid. Biotechnology Advances.13, 209-234.

Guillemant, P.M. and Drouard, L. (1992). Isolation of plant DNA: A fast, inexpensive and reliable method. Plant Mol Biol Rep. 10, 60-65.

Gupta, A. K and Kaur, N. (1997). Fructan storing plants - A potential source of high fructose syrups. Journal of Scientific and Industrial Research. 56, 447-452.

Haq, I., Sikander, A. Qadeer, M.A. and Javed, I. (2004).Citric acid production by selected mutants of Aspergillus niger from cane molasses. Bioresource Technology. 93, 125130.

Honecker, S., Bisping, B., Yang, Z. and Rehm, H. J. (1989). Influence of sucrose concentration and phosphate limitation on citric acid production by immobilized cells of Aspergillus niger. Applied Microbiology and Biotechnology. 31, 17-24.

Hossain, M.., Brooks ,J.D and Maddox, I.S. (1984)The effect of the sugar source on citric acid production by Aspergillus niger. Appl Microbiol Biotechnol .19:393-7.

Islam, M.S., Begum, R and Choudhary, N. (1986). Semipilot scale production of citric acid in cane molasses by gamma ray induced mutant of A. niger. Enz .Microbial Technol. $8,461-471$.

Kahlon, S.S. ,Kalra, K.L. ,Grewal, H.S, Arora, M. and Kaur, J. (1991) Citric acid production by immobilized cells of Aspergillus niger, J. Res. Punjab Agric. Univ. 28, 521528.

Khosravi-Darani, K. and Zoghi, A., (2008). Comparison of pretreatment strategies of sugarcane baggase: Experimental design for citric acid production. Bioresource Technology .99, 6986-6993.

Khosravi-Darani, K, Zoghi, A., Alavi, S.A. and Fatemi, S.S.A. (2008). Application of Plackett-Burman design for citric acid production from pretreated and untreated wheat straw, Iran. J. Chem. Eng. 2, 1-15.

Kirimura, K, Hirowatari, Y. and Usami, S. (1986).Alterations of respiratory systems in A.niger under the conditions of citric acid production . Agric. Biol. 5, 1299-1303.

Kubicek, C.P and R?hr M. (1989).Citric acid fermentation. Crit Rev Biotechnol.4:331-73.

Kumar D., Jain V.K., Shanker G. and Srivastava A. (2003). Utilisation of fruits wastes for citric acid production by solid state fermentation Process. Biochemistry. 38, 17251729.

Leo.V. S. (1983). Molasses in Animal Nutrition In Molasses General considerations.. National Feed Ingredients Association.C.Finttp:///rcrec-ona.ifas.ufl.edu/mol.pdf .
Lotfy,W.A., Khaled M.,and Ehab R. E (2007).Citric acid production by a novel Aspergillus niger isolate:I. Mutagenesis and cost reduction studies Bioresource Technology. 98, 3464-3469)

Marier, J. R. and Boulet, M. (1958). Direct determination of citric acid in milk with an improved pyridine-acetic anhyride method. J. of Dairy Science. 4, 1683-1692

Massoud. I. Mona.. (2004). An approach for utilization of agro-industrial wastes of sugar and sweeteners crops for natural antioxidant production. Mansoura Univ. J. Agric. Sci. 29, 2659-2672

Massoud, I Mona ,Abd El-Razek, M. Amal and Mahrous Hoda (2010). Bioproduction of fructose From chicory roots (cichorium intybus) and Jerusalem artichoke( Helianthus tuberosus )tubers . J.Fd.Sci.\&Technol.2.

Massoud, I,Mona., Wafaa, A. A \& Elgindy, A. A. (2009).Chemical and technological studies on chicory (Cichorium Intybus L) and its applications in some functional food. Journal of the Advances in Agricultural Researches.14,739-755.

Miller, G.L. (1959). Use of dinitrosalicylic acid reagent for determination of reducing sugar. Anal Chem 31, 426-428.

Monti,A., Amaducci,M.T.,Pritoni ,G. and Venturi G.(2005). Growth,

fructan yield, and quality of chicory (Cichorium intybus L.) as related to photosynthetic capacity, harvest time, and water regime. Journal of Experimental Botany . 56,13891395

Papagianni, M. (2007). Advances in citric acid fermentation by Aspergillus niger: Biochemical aspects, membrane transport and modeling. Biotechnol.Adv. 25, 244-263.

Patkai,G. and Barta,J. (2002). Nutritive Value of Different Jerusalem Artichoke Varieties. Ninth Seminar on Inulin. Budapest, Hungary. April 18-19.

Praznik,W.; Cieslik,E. and Filipiak-Florhiewicz,A. (2002). Soluble dietary fibers in Jerusalem artichoke powders: Compositional and application in bread. Nahrung/Food. 46,151-157.

Rohr, M., (1998). A century of citric acid fermentation and research.Food Technol. Biotechnol. 36, 163-171.

Roukas, T and Liakopoulou-Kyriakides M. (2002). Optimization study for the production of citric and gluconic acid from fig water extract by Aspergillus niger in surface fermentation .Food Biotechnology.16, 17-28.

Ruijter GJ and Visser J. (1999) Strain Improvement. In: Citric acid Botechnology. Kristiansen B, Mattey M,and Linden J. (eds). London: Taylor and Francis. pp. 55-68. 


\section{الملخص العربي}

\section{استخدام بعض مخلفات صناعة السكر والخاصيل المخزنة للأنيولين للإنتاج الحيوي لحامض الستريك}

منى ابراهيم مسعود، مني حسن بخيت

تم ف هذه الدراسة استخدام أثنين من مخلفات صناعة السكر

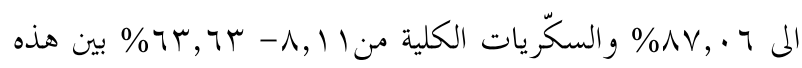
الخامات .أدى استخدام البيئة المحتوية على خليط بنسبة ا:إئي من جذور نبات الشيكوريا ومصاصة قصب السكر وأيضا المحتوية نبات الشيكوريا كمصدر كربون الحصول على أعلى عائد من حامض الستريك والكتلة الحيوية وأقل نسبة متبقية من السكريات بالمقارنة بالبيئات الغذائية التى تحتوى على الخامات الاخرى. فكان عائد حامض الستريكه؟ , سلجرام/لتر والنسبة المستهلكة من السكريات

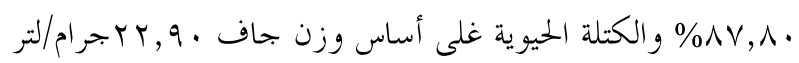

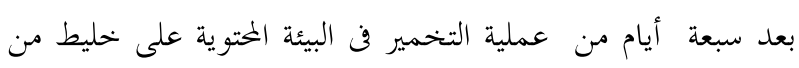
جذور نبات الشيكورياومصاصة القصب.

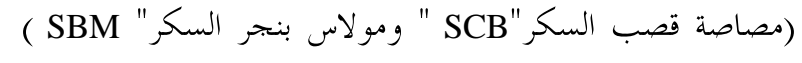
ومحصولين من المحاصيل المخزنة للأنيولين وهما جذور

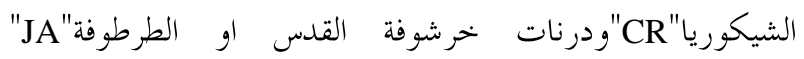
كمصدر للكربون أثناء الإنتاج الحيوي لحامض الستريك باستخدام سلالة فطر A. niger (GQ890276) السابق عزلها من مصاصة القصب. وقد وجد ان التركيب الكيماوى لتلك الخامات يؤثر على انتاج حامض الستريك. فلقد أختلف المحتوى الرطوبى من

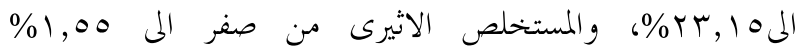

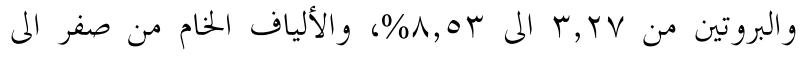

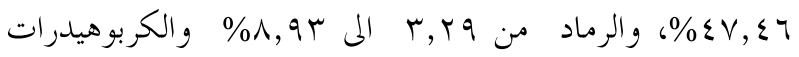
$\varepsilon \varepsilon, \wedge r$ من 